\title{
Regulation in Special Economic Region Tanjung Lesung, Pandeglang Regency, Banten Province, Indonesia
}

\author{
Dede Sri Kartini ${ }^{1}$, Rahman Mulyawan ${ }^{2}$, Muradi $^{3}$ \\ \{dedekartini@yahoo.com $\left.{ }^{1}\right\}$ \\ Universitas Pajajaran, Indonesia ${ }^{1.2,3}$
}

\begin{abstract}
Regulations which emphasize on economy growth while neglecting various public interest will stimulate capitalism in a region. By choosing research location at Special Economic Region (Kawasan Ekonomi Khusus/KEK) Tanjung Lesung in Pandeglang Regency, Banten Province, Indonesia, the researchers examine the rural areas which are transformed into investment place for everyone who has advantage in money. Capital owner play the role as controller for regional development. This is the center of capitalism, while governments only formulate regulations without monitoring how a rural area should be developed. Ironically, capitalism is supported by public policy. Tanjung Jaya Village once a rural area, now transformed into exclusive place with villa, resort, and beach tourism. This transformation has happened since this village became the first Indonesia Special Economic Region in tourism sector. The aim of this research will describe some regulations whic released by government, both central and local government i.e. Pandeglang Regency.
\end{abstract}

Keywords: Policy, Special Economic Zone, Rural Capitalism

\section{Introduction}

As mentioned in Law No. 39/ 2009 about Special Economic Zone (SEZ), it defined that the meaning of Special Economic Zone is a region with certain limits within the jurisdiction of the Unitary State of the Republic of Indonesia which is stipulated by conducting economic functions and obtaining certain facilities. Thus each SEZ performs the economic functions and special facilities provided by the Central Government, and this special facility is not available elsewhere. Thereby, the defining the function of economy and special facilities is what distinguishes between districts whom granted SEZs with districts elsewhere.

The economic functions contained in Law No. 39 are viewed from SEZ functions which include, conducting and developing businesses in trade, services, industry, mining and energy, transportation, maritime and fisheries, post and telecommunications, tourism and any others. Accordingly, KEK consists of one or more Zones, including export processing zones, logistics, industry, technological development, tourism, and energy whose activities can be intended for export and for the country. While the special facilities include fiscal facilities, in the form of taxation, customs and excise, local taxes and user charges, and non-fiscal facilities, in the form of land, licensing, immigration, investment and employment facilities, as well as other facilities and facilities that can be provided on Zones within SEZ, which shall be governed by the competent authority in accordance with the provisions of the laws and regulations. 
In accordance with Government Regulation No. 26 Year 2012, of SEZ Tanjung Lesung is designated as SEZ in Tourism, an area dedicated to tourism business activities to support the organization of entertainment and recreation, meetings, incentive trips and exhibitions, and related activities. What is the relevance of these rules and what are the impacts to the community and Local Government of Pandeglang Regency?

\section{Methodology}

This study uses a qualitative approach with descriptive research types.Data sources in qualitative research are words and actions, the rest are additional data such as documents and others. The words and actions of the people who were observed or interviewed were the main data sources.

\section{Result and Discussion}

As whatever the government wants to do or not to do. Meanwhile Nelson, citing Lawrence Mead, defines all rules are policy that guide government's practice, and those who carry out those rules have the authority inherently into their positions [1], [2]. Policy is interpreted by Dye public policy as: "an approach in political studies that analyzes governance relating to major public issues". Meanwhile, the authority that is part of decentralization is a responsibility that is being delegated to subordinates to make decisions based on the case at hand, but its supervision remains in the hands of the center [3]. The rules that are public policy in TanjungLesung SEZ will be analyzed below.

The twelve rules that guide the management of SEZ are in fact dominated by the rules that is being delegated to the Administrator. There are 7 rules about SEZ Administrator whose contents indicate the workload of Administrators, because they have to receive authority delegated from institutions or ministries, provinces as well as districts. At the Central level, the delegation of authority is obtained from the Investment Coordinating Board (BKPM) and the Ministry of Trade. The Ministry of Commerce delegates permissions that include: (1) Special Importer Identification Number (NPIK) for Electronics and its Components, (2) Special Importer Identification Number (NPIK) for Textile and Textile Products. (3) Special Importer Identity Numbers (NPIK) for Children's Toys (4) Registered Importers of Certain Products (IT-Specific Products) for Electronics (5) Registered Importers of Certain Products (IT-Specific Products) for Apparel (6) Registered Importers of Certain Products (IT-Specific Items) for Children's toys.

Meanwhile, the Provincial Administration delegates authority in processing Administration services, signing documents, issuing documents, permission and nonpermission sectors under the authority of Banten Provincial Government in TanjungLesung SEZ.As a result of that abundance of authority, the District level Administrators perform the following functions: (1) issuing permissions for SEZ management and business entities in TanjungLesung SEZ area; (2) submit periodic SEZ operational reports every 6 (six) months; (3) submit the SEZ operational report incidentally to the National Council or the Zone Council if there is a need to report the operationalization of SEZ outside the periodical report, or at the time the Administrator considers that there are conditions that has to be reported immediately; (4) provide guidance to SEZ management to improve the operationalization of SEZ; (5) give a reprimand to SEZ management in the event of any irregularities in SEZ operation; (6) give recommendation to the Minister / Head of Non Ministerial Government Institution, Governor, 
or Regent to obtain permits, facilities and conveniences which are based on the non-delegated law.

Generally, government can not escape from the globalization whom usually closely related to capitalism, but they can adapt and receive its effects [4]. Furthermore, globalization and public policy always perceived as contradictive because of: (1) Globalization considers heavily related to privatization and "technicalization " (2) Globalization is viewed forcing internalization of preferred capital by state and fiscal compression in public policy (3) Globalization is seen as reducing the nation's policy-making capacity and state autonomy, leading to the transfer of functions from public institutions to quasi-public institutions (independent central banks) and from national institutions to international institutions (IMF, World Bank, WTO) dominance. (4) Globalization produces "varieties of capitalism", thus much limiting the autonomy of public policy makers.

When the Central Government issues a policy, the regions will inevitably have to follow it. That is what happened with SEZ policy, as defines: "SEZ is a national policy that being implemented together with Provincial and District", said Joyce Irmawati as Head of Administration Office of TanjungLesung SEZ. Similarly, according to Ramdani, SEZ defined as a central government program, "we cannot refuse it, but we must prepare the community to face the impact of SEZ to our local religious content."It is not surprising that Pandeglang regency as the place for various policies in TanjungLesung SEZ, has not had the Regional Regulation of TanjungLesung SEZ, as revealed by Yangto.

In relation to the policy made by the local government of Pandeglang Regency, we do not possess (the regulations). Since it (SEZ policy) is a central government policy, we have not been able to follow up in the form of local regulations. However, if it is deemed necessary, the results of this primary study, for example, should recommend the formulation of local regulations, for this reason, of course we will form a Regional Regulation by incorporating these recommendations into Prolegda (Regional Legislation Program). So in order to answer the first question we have to say that, there is no law related to the SEZ.

From the statement, it is known that Pandeglang Regional Council is very open to recommendation to formulate Regional Regulation (Perda) related to SEZ. If the recommendation of this research is accepted by the DPRD, it will be incorporated into the Regional Legislation Program and will further transformed into Regulation soon . Nevertheless, although there is no Regional Regulation related to SEZ, Pandeglang Regent still supports the existence of TanjungLesung. This is because in TanjungLesung which is a rural area could experience unbalanced "relations between state, capital and citizens [5]. Whereas Yaysuria states that although capitalism promotes liberalism, there can still exist The Third Way, which is a system that combines liberalism for the interests of the market and socialism for common prosperity. Capitalism is a deregulated capital investment [6], but there is still a possibility to not to become individual.

However, according to other members of Parliament AgusRamdani, actually there is a regulation related to SEZ although it does not directly mentioned as SEZ, namely Regional Regulation No. 6 of 2014 on Tourism Master Plan 2015-2025.In particular, our law did not formulated for KEK. But there is embodied in Regional Regulation no 6/2014 on Tourism Master Plan 2015-2025. There is designated regulation, which is suitable for SEZ. Incidentally, me and the committee, to compensate for KEK, sorry to say but, we viewed (the establishment of KEK) has higher negative impacts (on our society). Well, in order to balancing the condition, we designated (inside the Regulation) a chapter on the construction of Mosque tours. Because after all, Pandeglang is a santri/ religious city,(this chapter is mean to) 
minimize the risk, thus we formulated this Law. But unfortunately, until this day, it cannot be absorbed yet.

Many policies should have been taken by local government to support SEZ, for example with the change of RT/RW, as well as its policy related to SEZ. Then, the Regent also made a Regent's Decree twice, firstly, on community relocation, second about the development plan. Furthermore, the regional council will only support the budget related to SEZ region.

In accordance with Government Regulation No. 96 of 2015 on Facilities and Conveniences of SEZ, the central government should provide various conveniences to investors in the form of taxation, customs and excise, goods traffic, employment, immigration, land, and both of permission and non permission services. Aside from those various conveniences, government also burdened with the development of high-cost infrastructure. This is done to achieve society' welfare by using modernization approach of historical perspective.

When this SEZ policy has not been finished its accessibility, and still has low feasibility, it will still be difficult to attract investment. The airport has not been built yet, the toll has not been built yet, while accessibility is the most sensitive consideration for investors. So, the strategy, while waiting for its accessibility, Local Government should have enliven the area, create a festival, prepare the community, and prepare its homestays. When the SEZ is all ready, and its supporting infrastructure is available, there will be no heavy market competition o between business actors in the SEZ area, by creating buffer-zone, because both have their respective target market. For the region inside, the government projects should targeted the upper-middle class market, while the buffer-zone is expected in targeting the lower middle class market since it will more attract domestic tourists whom will stay at home stay, while the intern region is designated for foreign customers. Finally, the government hopes to avoid the exclusivity of this SEZ region. This synergy is guarded by the SEZ Administrator Officer, so hopefully it will produce a series a partnership, not a competition. The SEZ policy still has not become a pragmatic policy Nugroho [7], which defines as ethical policy and fulfill public interest.

\section{Conclusion}

The Central Government creates rules with the consequences that must be done by the government itself. The creation of SEZ rules requires government to build infrastructure such as road access, airport and railway access, in addition to the various facilities provided to investors. Although infrastructure development is an obligation, so far only access roads that have been implemented. Communities affected by the SEZ rules, there are people who have to move to a neighboring village. if not moved the potential conflict with SEZ managers is inevitably. Fishermen become difficult to go to sea, because the beach is full of hotels. Furthermore, other land-related conflicts also arise, with multiple land certificates being circulated.

\section{References}

[1] D. Indiahono, Kebijakan Publik: Berbasis Dynamic Policy Analysis. Yogyakarta: Gava Media, 2009.

[2] B. J. Nelson, R. E. Goodin, and K. H. Dieter, "Public Policy and Administration," in $A$ New Handbook of Political ScienceA New Handbook of Political Science, New York: Oxford University Press Inc, 1996.

[3] R. . Keohane, D. D. John, and J. S. Nyeand, "Introduction," in Governance In A 
Globalizing World, Washington: BrookingInstitution Press, 2000.

[4] Sarundajang, Arus Balik Kekuasaan Pusat ke Daerah. Jakarta: Kata Hasta Pustaka, 2011.

[5] S. Eko, "Mutiara Perubahan : Inovasi dan Emansipasi Desa Dari Indonesia Timur :," ACCESS Phase II dan IRE, 2013.

[6] I. G. Saksono, Bahaya Kapitalisme. Jakarta: Ampera Utama, 2015.

[7] D. R. Nugroho, Kebijakan Publik Formulasi, Implementasi dan Evaluasi. Jakarta: PT. Gramedia, 2004. 